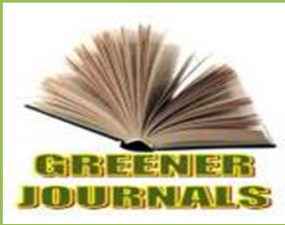

\title{
Haematological and Serum Biochemical Indices of Growing Cockerels Fed Varied Levels of Azolla-Turmeric Mixture
}

\author{
Alagbe J. 0.
}

Dan-malafia Farms Limited, Ibadan

ARTICLE INFO

Article No.: 090117117

DOI: 10.15580/GJAS.2017.7.090117117

Submitted: 01/09/2017

Accepted: 04/09/2017

Published: 15/09/2017

${ }^{\star}$ Corresponding Author

Alagbe J. $O$.

E-mail: demsonfarms@yahoo.

com

\section{Keywords:}

growing cockerels, haematological parameters, biochemical indices,

Azolla-turmeric mixture
This study was conducted to examine the haematological and some serum biochemical indices of growing Isa cockerels fed diets supplemented with Azollaturmeric mixture. One hundred and twenty (120) four weeks old Isa white cockerels were divided into four groups with three replicates, each of ten birds in a completely randomized design. Treatment 1 was fed basal diet without Azolla turmeric mixture (ATMP), treatment 2, 3 and 4 were fed basal diets supplemented with ATMP at levels 5, 10 and 15\% respectively. Proximate analysis shows that Azolla powder contained $22.51 \%$ crude protein, $3.53 \%$ ether extracts, $14.13 \%$ ash, $18.15 \%$ crude fibre and $37.88 \%$ nitrogen free extract while turmeric powder contained $9.14 \%$ crude protein, $2.40 \%$ ether extracts, $8.69 \%$ ash, $4.10 \%$ crude fibre and $69.10 \%$ nitrogen free extracts. The basal diet was formulated to meet the nutritional requirements of birds according to NRC (1994).

All the hematological parameters evaluated : Pack cell volume (PCV), Haemoglobin (Hb), White blood cell (WBC), Red blood cell (RBC), Mean corpuscular haemoglobin concentration (MCHC), Mean corpuscular volume (MCV), Mean corpuscular haemoglobin $(\mathrm{MCH})$ were not significantly $(P>0.05)$ affected by the inclusion of ATMP. However, there were no significant $(P>0.05)$ differences among all treatment groups in the values of total protein, albumin, globulin, alkaline phosphatase, uric acid, creatinine, SGPT and SGOT throughout the experiment which lasted for 90days. It was concluded that Azolla -turmeric mixture could be added up to $15 \%$ in the diet growing cockerels without any adverse effects on their blood profile. 


\section{INTRODUCTION}

Poultry production in Nigeria is faced with a lot of problems, one of which is high feed cost. According to Ekenyem (2001), feed cost represents about $70-80 \%$ of the total cost of production. The increase in the prices of conventional feedstuffs like soya meal, fishmeal and maize which are highly used in the production of livestock feed, flour milling, oil industries as well as human consumption is as a result of the competition between humans and animals for grains and upward increase in human population. Profit cannot be maximized unless birds are well fed with formulated diets at reasonable cost to meet up with their nutritional requirement, therefore there is need to look for cheaper alternative sources of feed ingredients to feed livestock. For instance, Azolla is unconventional feed that can be used as a plant protein source in poultry nutrition. According to Alalade and lyayi (2006) their leaves are small, sensitive with different colours. Azolla is a water fern belonging to the family Azollaceae and order pteridophyta, it is rich in essential amino acids, protein, vitamins and minerals like calcium, phosphorus, potassium, magnesium, copper and iron and can therefore be advantageously used for animal fodder.

Turmeric (Curculum longa) is a tropical plant which contains high biologically active compounds such as curcumin, bismethoxycurcumin and dimethoxycurcumin. Turmeric powder is a bright yellow powder made from dry grinding of turmeric rhizomes. According to Chattopadhyay et al (2004), turmeric contains $6.3 \%$ protein, $5.1 \%$ fat, $13.1 \%$ moisture, $69.4 \%$ carbohydrates and $3.5 \%$ minerals. Its yellow pigment (Curcumin) has a high therapeutic value; several reports have shown that $2-5 \%$ turmeric is curcumin (Agarwal et al, 2001) and it's relatively rich in starch (Mangala and Mathew, 1986). Curcumin are excellent source of phenolic compounds, ascorbic and carotenoids which have been reported to show good antioxidant activity (Huda-faujan et al, 2009; M. Kamal et al, 2014).

According to Kurtoglu et al (2005); Ajao et al (2013), nutrition or dietary contents affect the blood profile of healthy animals. Heamato-biochemical analyses are used for nutritional studies for animals (Onyeanusi, 2007); Church et al (1984); Olabanji et al (2007). Hematological values could serve as baseline information for comparisons of nutrient deficiency (Etim et al (2014a); Daramola et al (2005). According to Azzez et al (2009); Yanagita et al (2011); Adeyemo et al (2010) factors such as age, sex, nutrition, environmental condition and management could cause variation in haemato-biochemical parameters. Blood examination gives a clear picture to determine the presence of metabolites and other constituents in the body. Therefore, this experiment was carried out to investigate the haematological and some serum biochemical parameters of Isa cockerels fed different levels of Azollaturmeric mixture.

\section{MATERIALS AND METHODS}

\section{Site of the experiment}

The study was carried out at the Poultry unit of Danmalafia Farms, Ibadan, Nigeria.

\section{Preparation of experimental diets}

Fresh Azolla was harvested from the propagation pond within the farm premises and washed thoroughly to remove residues, it was later placed on flat metal trays and sun dried for 5 days until the leaves turns brown and crumbles when squeezed. It was then milled into Azolla powder.

The turmeric rhizome (dry roots) were collected, sun-dried for 8 days and milled to produce turmeric powder. Thereafter, Azolla-Turmeric (ATMP) was mixed together in the ratio of $1: 1$ to formulate the diet along with other ingredients purchased from a reputable feed mill in Ibadan.

All the experimental diets were formulated to meet the nutritional requirement of birds according to NRC (1994) as presented in Table 1. The proximate composition of Azolla and Turmeric powder is presented in Table 2 and 3 respectively.

Treatment 1- Control 0\% Azolla-Turmeric mixture (Basal diet)

Treatment 2- Basal diet $+5 \%$ Azolla - Turmeric mixture Treatment 3- Basal diet $+10 \%$ Azolla-Turmeric mixture Treatment 4 - Basal diet $+15 \%$ Azolla-Turmeric mixture

\section{Animals and their management}

A total of One hundred and twenty, four weeks old Isa white cockerels were randomly distributed into four (4) groups of 30 birds. Each group was further subdivided into 3 replicates with 10 birds per each in a Completely Randomized Design. A deep litter poultry house was used; the house was cleaned and well disinfected before the commencement of the experiment. Vaccines were administered according to the prevailing vaccination schedule in the environment. Feed and water were offered ad-libitum. The light was continuous throughout the experimental period that lasted for 90days.

\section{Blood Analysis}

At day 90, three birds were randomly selected from each replicate for hematological and serum analysis. Samples meant for hematology were collected into bottles containing Ethylene diamine tetra acetic acid (EDTA) as anticoagulant, while that of serum analysis was free from anticoagulant. Blood samples were taken from the brachial vein, the hematological parameters analyzed 
included Pack cell volume (PCV), hemoglobin concentration $(\mathrm{Hb})$, Red blood cell (RBC), white blood cell (WBC) and its differential counts (Eosinophils, monocytes, lymphocytes and neutrophils), Mean corpuscular volume (MCV), Mean corpuscular haemoglobin $(\mathrm{MCH})$, Mean corpuscular haemoglobin concentration (MCHC). PCV, RBC, WBC and $\mathrm{Hb}$ were measured according to Dein (1984). MCV, $\mathrm{MCH}$ and $\mathrm{MCHC}$ were recorded according to Ritchie et al (1994).

Serum total protein, Albumin, Globulin, Uric acid, Creatinine and Blood glucose were determined using
Scott (1965), Alkaline phosphatase, Serum glutamic oxalocaetate transaminase (SGOT) and Glutamic phosphate transaminase (SGPT) were recorded according to Reitman and Frankel (1957).

\section{Statistical Analysis}

All data collected were subjected to one way analysis of variance (ANOVA) using SAS 1994 and significant means separated by Duncan multiple range tests. (Duncan, 1955).

Table 1: Composition of experimental diets (\%)

\begin{tabular}{|c|c|c|c|c|}
\hline \multirow[t]{2}{*}{ Ingredients } & \multicolumn{4}{|c|}{ Diets } \\
\hline & 1 & 2 & 3 & 4 \\
\hline Maize & 55.00 & 55.00 & 55.00 & 55.00 \\
\hline Wheat offal & 26.00 & 26.00 & 26.00 & 26.00 \\
\hline Soya meal & 10.00 & 10.00 & 10.00 & 10.00 \\
\hline Ground nut cake & 5.00 & 4.80 & 4.60 & 4.40 \\
\hline Limestone & 1.00 & 1.00 & 1.00 & 1.00 \\
\hline Bone meal & 2.00 & 2.00 & 2.00 & 2.00 \\
\hline Lysine & 0.25 & 0.25 & 0.25 & 0.25 \\
\hline Methionine & 0.20 & 0.20 & 0.20 & 0.20 \\
\hline Premix ${ }^{*}$ & 0.25 & 0.25 & 0.25 & 0.25 \\
\hline Salt & 0.30 & 0.30 & 0.30 & 0.30 \\
\hline Tridax meal & - & 0.20 & 0.40 & 0.60 \\
\hline Total & 100.00 & 100.00 & 100.00 & 100.00 \\
\hline \multicolumn{5}{|c|}{$\begin{array}{lcccc}\text { Chemical composition } & & & \\
\text { Crude protein } & 18.18 & 18.70 & 18.87 & 18.97 \\
\text { ME (Kcal/kg) } & 2804.1 & 2820.5 & 2821.4 & 2821.6 \\
\text { *Premix supplied per kg diet :- Vit A, 10,000 I.U; Vit E, 5mg; Vit D3, 3000I.U, Vit K, 3mg; Vit B2, 5.5mg; Niacin, } & \\
\text { 25mg ; Vit B12, 16mg ; Choline chloride, 120mg ; Mn, 5.2mg ; Zn, 25mg ; Cu, 2.6g ; Folic acid, 2mg ; Fe, 5g ; } & \end{array}$} \\
\hline \multicolumn{5}{|c|}{ Table 2: Proximate Composition of Turmeric Powder } \\
\hline Parameter & & & Dry matter & \\
\hline Moisture & & & 9.57 & \\
\hline Crude protein & & & 9.14 & \\
\hline Ether extracts & & & 2.40 & \\
\hline Total ash & & & 8.69 & \\
\hline Crude fibre & & & 4.10 & \\
\hline NFE & & & 69.10 & \\
\hline
\end{tabular}

NFE: Nitrogen Free Extracts

Table 3: Proximate Composition of Azolla Powder

\begin{tabular}{lc}
\hline Parameter & Dry matter $(\%)$ \\
\hline Crude protein & 22.51 \\
Ether extracts & 3.53 \\
Total ash & 14.13 \\
Crude fibre & 18.15 \\
NFE & 37.88 \\
\hline
\end{tabular}

NFE: Nitrogen Free Extracts 
Table 4: Hematological parameters of growing Cockerels fed diets supplemented with varying levels of ATMP

\begin{tabular}{lccccc}
\hline & \multicolumn{5}{c}{ Treatments } \\
\hline Parameters & 1 & 2 & 3 & 4 & SEM \\
\hline Pack cell volume $(\%)$ & 30.01 & 31.13 & 30.77 & 30.76 & 1.10 \\
$\mathrm{Hb}(\mathrm{g} / \mathrm{dl})$ & 9.84 & 10.22 & 10.36 & 10.44 & 0.06 \\
Red blood cell count $\left(\times 10^{6 / \mathrm{ml}}\right)$ & 3.31 & 3.19 & 3.10 & 3.02 & 0.18 \\
White blood cell count $\left(\times 10^{6 / \mathrm{ml}}\right)$ & 4.14 & 4.89 & 4.53 & 4.94 & 1.03 \\
MCV (fl) & 101.2 & 118.1 & 102.1 & 106.7 & 2.88 \\
MCH (pg) & 34.09 & 34.90 & 34.99 & 34.09 & 0.51 \\
MCHC (g/dl) & 33.19 & 34.16 & 34.87 & 34.89 & 0.66 \\
Neutrophils $(\%)$ & 3.11 & 3.27 & 3.38 & 3.41 & 0.50 \\
Lymphocytes $(\%)$ & 40.08 & 41.72 & 47.01 & 48.13 & 1.70 \\
Eosinophils $(\%)$ & 4.23 & 4.36 & 4.40 & 4.57 & 0.33 \\
Monocytes (\%) & 3.26 & 3.34 & 3.37 & 3.41 & 0.17 \\
\hline
\end{tabular}

$\mathrm{Hb}$ : Haemoglobin

MCV: Mean corpuscular volume

$\mathrm{MCH}$ : Mean corpuscular haemoglobin

MCHC: Mean corpuscular haemoglobin concentration

Table 5: Serum biochemistry of growing Cockerels fed different diets supplemented with ATMP

\begin{tabular}{lrrrrr}
\hline \multicolumn{5}{c}{ Treatments } \\
\hline Parameters & 1 & 2 & 3 & 4 & SEM \\
\hline Albumin (g/dl) & 2.11 & 2.05 & 2.10 & 2.06 & 0.48 \\
Globulin (g/dl) & 1.01 & 1.10 & 1.08 & 1.07 & 0.13 \\
Total protein $(\mathrm{g} / \mathrm{dll})$ & 3.12 & 3.15 & 3.18 & 3.13 & 0.01 \\
Uric acid (mol/dl) & 5.01 & 5.07 & 5.09 & 5.02 & 0.14 \\
Creatinine (mol/dl) & 3.07 & 3.08 & 3.14 & 3.03 & 1.01 \\
ALP (iu/l) & 56.01 & 53.12 & 50.44 & 51.66 & 1.47 \\
SGPT (U/l) & 31.07 & 32.11 & 31.50 & 31.53 & 0.05 \\
SGOT (U/l) & 30.23 & 30.91 & 31.46 & 30.41 & 0.11 \\
\hline
\end{tabular}

SGPT: Serum glutamic phosphatase transaminase

SGOT: Serum glutamic oxaloacetate transaminase

ALP: Alkaline phosphatase

\section{RESULTS AND DISCUSSION}

Table 1 shows the percentage composition of experimental diet. The value of the crude protein ranges between $18.18 \%$ and $18.97 \%$ while the energy level is between 2804.1 and 2821.6 (ME Kcal $/ \mathrm{kg}$ ). The basal diet was formulated to meet the nutrient requirements of birds according to NRC (1994).

The proximate composition of turmeric is shown in Table 2. The proximate components of turmeric are $9.57 \%, 9.14 \%, 2.40 \%, 8.69 \%, 4.10 \%$ and $69.10 \%$ for moisture, crude protein, ether extract, ash, crude fibre and nitrogen free extract, the results obtained agrees with the findings of Ikepeama et al (2014) and Alagbe, J.O (2016) on the chemical composition of turmeric. Table 3 reveals the proximate composition of Azolla powder, the proximate content of Azolla contains $22.51 \%, 18.15 \%, 3.53 \%, 37.88 \%$ and $14.13 \%$ for crude protein, crude fibre, ether extract, nitrogen free extract and total ash. The values recorded in this study were within the range reported by Alalade and lyayi (2006); Alagbe, J.O (2017).

Table 4 shows the Hematological parameters of growing Cockerels fed diets supplemented with varying levels of ATMP. Pack cell volume (PCV) values obtained are $30.01 \%, 31.13 \%, 30.77 \%$ and $30.76 \%$ for treatments $1,2,3$ and 4 respectively while those of Haemoglobin $(\mathrm{Hb})$ are 9.84, $10.22,10.36$ and $10.44(\mathrm{~g} / \mathrm{dl})$ for treatments 1,2, 3 and 4 . The values obtained for Red blood cell (RBC) are $3.31,3.19,3.10$ and $3.02\left(\times 10^{6 /} \mathrm{ml}\right)$ for treatments 1,2, 3 and 4 respectively while those of MCV are 101.2, 118.1, 102.1 and 106.7 (fl) for treatment $1,2,3$ and 4 respectively. $\mathrm{MCH}$ values obtained are $34.09,34.90,34.99$ and $34.09(\mathrm{pg})$ for treatments $1,2,3$ and 4 respectively while those of $\mathrm{MCHC}$ are 33.19 , 34.16, 34.87 and $34.89(\mathrm{~g} / \mathrm{dl})$ for treatments $1,2,3$ and 4. Pack cell volume (PC V), Heamoglobin $(\mathrm{Hb})$, red blood cell (RBC), mean corpuscular volume (MCV), mean corpuscular haemoglobin ( $\mathrm{MCH})$ and mean corpuscular haemoglobin concentration $(\mathrm{MCHC})$ were 
not significantly $(P>0.05)$ different among the dietary treatments. However, all values fall within the range reported by Talebi et al (2005); Kececi and Col (2011); Wiki vet (2013) and Abdi-Hachesoo et al (2011) of chicken. According to Togun et al (2007) physiological and nutritional status of animals could cause differences in haematological parameters.

Campbell and Lasley (1975) also reported that when the haematological parameters were within the normal range, it is a clear indication of adequate nutritional status. Although, the PCV and $\mathrm{Hb}$ values slightly increases as the level of ATMP increased though not at a significant level. High level of $\mathrm{Hb}$ and $\mathrm{RBC}$ is an index of efficient oxygen and carbon dioxide transportation within the body of the animal, PCV are also involved in the transport of absorbed nutrients. According to Togun et al (2007) an increase in PCV and RBC level shows more efficient erythropoiesis in animals. $\mathrm{MCV}, \mathrm{MCH}$ and $\mathrm{MCHC}$ vital parameters used to ascertain anaemic conditions in the experimental animals (Saleh at al., 2014).

White blood cells values obtained are $4.14,4.89$, 4.53 and $4.94\left(\times 10^{6 /} \mathrm{ml}\right)$ for treatments $1,2,3$ and 4 respectively while the Neutrophils values are $3.11 \%$, $3.27 \%, 3.38 \%$ and $3.41 \%$ for treatments $1,2,3$ and 4 respectively. Lymphocytes values obtained are $40.08 \%$, $41.72 \%, 47.01 \%$ and $48.13 \%$ for treatments $1,2,3$ and 4 respectively. White blood cells (WBC), lymphocytes, neutrophils, monocytes and eosinophils were not significantly $(P>0.05)$ influenced by the different inclusions of ATMP, their values slightly increased from treatment 1 to 4 but fall within the normal range reported by Ibrahim Albokhadaim (2012) on the haematological values of indigenous chicken. According to Ameen et al (2007) ; Adenkola and Durotoye (2004) a normal range of WBC, lymphocytes, monocytes, neutrophils and eosinophils shows that the feeding pattern did not affect the immune system of the birds.

The results of the serum biochemical analysis (Table 5) showed that total protein values obtained are $3.12,3.15,3.18$ and $3.13(\mathrm{~g} / \mathrm{dll})$ for treatments $1,2,3$ and 4 respectively, while the albumin values are $2.11,2.05$, 2.10 and $2.06(\mathrm{~g} / \mathrm{dl})$ for treatments $1,2,3$ and 4 . The values obtained for globulin in $\mathrm{g} / \mathrm{dl}$ are 1.01, 1.10, 1.08 and 1.07 for treatments $1,2,3$ and 4 respectively. Albumin, globulin and total protein were not $(P>0.05)$ significantly different among the dietary treatments. The values for all parameters fall within the normal range established for birds by Swenson (1970); Olorede and Longe (2002) for birds. This observation reveals that the quality of protein in the experimental diet is enough to support normal protein reserves across the treatment. Uric acid values obtained in $\mathrm{mol} / \mathrm{l}$ are $0.31,0.37,0.39$ and 0.32 for treatments $1,2,3$ and 4 respectively while those of creatinine are $0.77,0.78,0.79$ and $0.73(\mathrm{~mol} / \mathrm{l})$ for treatments $1,2,3$ and 4 respectively. ALP values obtained are 56.01, 53.12, 50.44 and 51.66 (iu/l) for treatments 1, 2, 3 and 4 respectively. Uric acid, creatinine and ALP were not significantly affected ( $P$ $>0.05$ ) by the dietary inclusion of ATMP. The uric acid and creatinine values slightly increased from treatments 1 to 3 after which the values declined. According to Ibrahim Albokhadaim (2012), uric acid is major product from nitrogen metabolism. The uric acid and creatinine values agree with the reports of Bolu et al (2009) on the serum biochemistry of broiler chickens but contrary to the reports of Saleh et al (2014) on biochemical indices of rabbits fed graded levels of browse forage. The ALP values $(50.44-56.01 \mathrm{iu} / \mathrm{l})$ were contrary to the (69.25$79.00 \mathrm{iu} / \mathrm{l})$ reported by Bolu et al (2009) for broiler chickens.

The SGPT values obtained are $31.07,32.11$, 31.50 and $31.53(\mathrm{U} / \mathrm{I})$ for treatments $1,2,3$ and 4 respectively while those of SGOT in (U/l) are 30.23 , $30.91,31.46$ and 30.41 for treatments $1,2,3$ and 4 respectively, the values were not significantly $(P>0.05)$ influenced by the different inclusion of ATMP. The SGPT and SGOT values of $31.07-31.53(\mathrm{U} / \mathrm{l})$ and $30.23-$ $31.46(\mathrm{U} / \mathrm{l})$ were comparable to $33.03-36.99(\mathrm{U} / \mathrm{l})$ and $30.38-33.58(\mathrm{U} / \mathrm{l})$ respectively reported by Tyas et al (2013) but contrary to the reports of Alagbe, J.O (2016) on the effects of feeding varying levels of tiger nut on the blood profile of grass cutters. According to lyayi (1994) SGPT and SGOT are mostly influenced by the presence of anti-nutrients in an experimental diet, this observation suggests that the animals were able to tolerate the antinutrients in turmeric. Alagbe, J.O (2017) reported the presence of saponin, alkaloid, tannin, sterol, phenol and flavenoid at $1.03 \%, 0.66 \%, 1.01 \%, 0.02 \%, 0.72 \%$ and $0.38 \%$ respectively during the phytochemical analysis of turmeric powder.

\section{REFERENCES}

Agarwal M, Walia S, Dhingra S, Khambay BPS (2001) Insect growth inhibition, antifeedant and antifungal activity of compounds isolated /derived from Zingiber officinale Roscoe (ginger) rhizomes. Pest Management Science 57:289-300.

Adeyemo, G. O., Ologhobo, A.D and Adebiyi, O. A (2010) The effect of graded levels of dietary methionine on the heamatology and serum biochemistry of broilers. Int. Journal of Poult. Sci 9(2): 158-161.

Azzez, O. I., Oyagbemi, A. A and Oyewale, J. O (2009) Diurnal fluctuation in heamatological parameters of domestic fowl in the hot humid tropics. Int. Journal of Poult. Sci 8(3): 247-251.

Alagbe, J.O (2017). Growth performance and blood parameters of weaner pigs fed diets supplemented with turmeric powder (TUP). Scholarly Journal of Agricultural Science Vol 7(2), Pages 57-61. March, 2017. Available online at http:www.scholarlyjournals.com/SJAS ISSN 2276-7118 $\quad$ C 2017 Scholarly-Journals

Ajao, B. H., Ola, S. I., Adameji, O. V., Kolawole, R. F (2013) The relationship of ambient temperature and relative humidity to the thermorespiratory function of 
greater grass cutter. Proc. of the $18^{\text {th }}$ Annual Conf. Animal Sci. Assoc. of Nig 92.

Adenkola, A. Y and Durotoye, L.A (2004) Haematological study during pre-partum periods in brown savannah does in Zaria, Nig. Proc. of $38^{\text {th }}$ Annual Conf. of the Agric Soc. Of Nig. 538-540.

Ameen, S. A., Adedeji, O. S., Akingbade, A. A., Olayeni, T. B., Ojedapo, L. O and Aderinola, A (2007) The effects of different regimes on haematology parameters and immune status of commercial broilers in derived savannah zone of Nigeria. Proc. of $32^{\text {nd }}$ Annual Conf. Nig. Soc. Of Ani. Prod. 146148.

Alagbe, J.O (2016). Effect of feeding varying levels of tiger nuts (Cyperus esculentus) seed meal on the performance and blood profile of Weaner grass cutters. Scholarly Journal of Agricultural Science Vol 7(1), Pages 15-19. Feb, 2017. Available online at http:www.scholarly-journals.com/SJAS

Alalade, O.A and lyayi, E. A (2006). Chemical composition and the feeding value of Azolla meal for egg type chicks. Int'l Jou. Of Poult. Sci. 5(2): 137141.

Abdi-Hachesoo, B., Talebi, A and S. Asri-Rezaei (2011) Comparative study on blood profiles of Indigenous and Ross-308 Broiler breeders. Global Vet., 7:238241

Campbell, J. R and Lasley, J. F (1975) The science of animal that serve man. $2^{\text {nd }}$ edn McGraw Hill Book Company New York, USA 200-202.

Church, J. P., Judd, J. T., Young, C.W., Kebay, J. L and Kim, W. W (1984). Relationship among diet constituents and specific serum clinical components of subjects eating self selected diets. Afr. Jour. Clin. Nutr. 40:1338-1344.

Chattopadhyay, I., Biswas, K., Bandyopadhyay, U and Banerjee, R.K (2004) Turmeric and Curcumin: Biological actions and medicinal applications. Curr Sci. 87:44-53.

Dein, F. J (1984) Laboratory manual of avian heamatology. Association of Avian Veterinarian, East North Port, USA.

Daramola, J. O., Adeloye, A. A., Fatoba, T. A and Soladoye, A. O (2005) Haematological and biochemical parameters of WAD goats. Livestock Res. For Rural Dev. 17(8) Available at: http://www.irrd.org17/8/clara/17095.htm.

Etim, N. N., Enyenihi, G. E., Akpabio, U and Offiong, E. $E(2014 a)$ Effects of nutrition on the heamatology of rabbits: A review. European Scientific Journal, 10(3):413-424

Ekenyem (2001) Response of broiler chicks to diets supplemented with garlic essential oil as natural growth promoter. Int. Journal of Science and Research Vol3 Issue 5 May 2001.

Swenson, M. J (1970) Physiologic properties, cellular and chemical constituents of blood. In: Dukes' Physiology of Domestic Animals, $8^{\text {th }}$ Edition
Comstock publishing Associates, Cornell University Press, Ithaca and London, UK. Pp 21-26

Olorede, B. R and Longe, O. G (2002) Effect of replacing palm kernel cake with sheabutter cake on egg quality and serum chemistry of laying hens. Nig. Journal. Prod. 27: $19-23$.

Olabanji, R. O., Farinu, G. O., Akinlade, J. A and Ojebiyi, O. O (2007) Growth performance and heamatological characteristics of weaner rabbits fed cyanide in processed cassava peel meals on heamatological and biochemical indices of growing rabbits. Proc. of the $35^{\text {th }}$ Annual Conf. Nigeria Society of Anim. Prod. 212.

lyayi, E. A (1994). Supplemental effect of low and high cyanide cassava on the performance, nutrient digestibility and serum metabolites of growing pigs. J. Agric. Trop. Sub-trop 95:199-205.

Ikepeama, N., Tayyem, R.F and Rock, C.L (2014). Curcumin content of turmeric and curry powders. Nutr.Cancer.55(2) 126-31.

NRC, National Research Council (1994) Nutrients Requirements of Poultry. ( $9^{\text {th }}$ rev. Ed). National Academy Press. Washington D.C USA.

Huda-faujan., Noriham, A., Norrakiah, A and Babji, A (2009). Antioxidants activity in plants methanoic extracts containing phenolic compounds. African Journal of Biotechnology 8(3): 484-489.

Isaac, O.S (2013). Haematological parameters and factors affecting their values, Published by Science and Education Centre of North America. Agricultural science Volume 2, Issue 1 (2014), 37-47. ISSN 2291-4471.

Kececi, T and R. Col (2011) Haematological and biochemical values of the blood of pheasants of different ages. Turkish Journal of Veterinary and Animal Science. 35:149-156.

Kamal, M.E Youssef., Amira M. El Newihi., Soad M. Omar and Zeinab S. Ahmed (2014) Assessment of proximate chemical composition, nutritional status and antioxidants of curcumin and mustard seed powder. Food and Public Health 2014, 4(6): 286292.

Duncan, D.B. (1955). Multiple Range and Multiple F-Test Biometrics 11:1-42

Ibrahim Albokhadaim (2012). Haematological and some biochemical values of indigenous chickens in AlAhsa, Saudi Arabia during summer season. Asian Journal of Poultry Sciences. 6(4):138-145, 2012.

Daramola, J. O., Adeloye, A. A., Fatoba, T. A and Soladoye, A. O (2005) Heamatological and serum biochemical parameters of WAD goats. Livestock. Res. For Rural Dvp. 17(8)

Etim NseAbasi N., Glory E Enyenihi., Uduak, Akpabio and Edem, E. A Effiong (2007). Heamatological parameters indicators of the physiological state of farm animals. British Journal of Science 10(1): 3345.

Bolu, S.A.O., Sola-Ojo, F.E ., Olorunsanya, O.A and Idris, K (2009) Effect of graded levels of dried 
pawpaw seed on the performance, heamatology , serum biochemistry and carcass evaluation of broiler chicken. Int. Journal of Poultry Sci. 8(9):905-909, 2009.

Talebi, A., Asri-Rezaei, S., Rozeh-Chai, R and Sahraei, $R$ (2005). Comparative studies on haematological values of broiler strains ( Ross, Cobb, Arbo-acres and Arian). Int'l Journal of Poultry Sci., 4:573-579.

Togun, V. A., Oseni, B.S. A., Ogundipe, J.A., Arewa, T. R., Hammed, A. A., Ajonijebu, D.C., Oyeniran, A., Nwosisi, I and Mustapha, F (2007) Effects of Chronic Lead Administration on the Haematological Parameters of Rabbits- A Preliminary Study. Proc of the $41^{\text {st }}$ Conf. of the Agric. Soc. Of Nig., 341

Ritchie, B.W., J. G. Harrison and R.L. Harrison (1994) Avian Medicine, Wingers Publishing Inc. Florida.

Reitman, S and Frankel, S (1957) Method for serum analysis using the colorimetric SGOT/SGPT assay. Animal Journal of Clinical Pathology.

SAS Institute (1994) SAS / STAT users guide. Version $6.1,3^{\text {rd }}$ Ed. SAS Inst., Cary, N.C

Scott, H.M (1965) Measurement of the amino acid content of fish meal protein by chick growth assay. Poult. Sci Pp: 365-395

Saleh, J. L., Njidda, A. A., Adeniji, A.A and Lawan, G. B (2014) Haematological and Biochemical Indices of Rabbits fed Graded Levels of Browse Forage in Semi Arid Environment. Global Journals Inc (2014).
Wikivet. Haematology ; 2013. Available at: www.enwikipedia/wiki/haematology

Tyras Rini Saraswati., Wasmen Manalu., Damiana Rita Ekastuti and Nastiti Kusumorini (2013) Increased egg production of Japanese quail by improving liver function through turmeric powder supplementation. International Journal of Poultry Science 12(10): 601614 (2013).

Kurtoglu, F., Kurtoglu, V., Celik, I., Kececi, I and Nizamlioglu, M (2005) Effect of dietary boron supplementation on some biochemical parameters, peripheral blood lymphocytes, splenic plasma cells and bone characteristics of broiler chicks given diets with adequate or inadequate cholecalciferol content. Br. Poultry Sci., 46:87-96.

Onyeanusi, L. (2007). Hematological and Serological Characteristics of Cockerels Fed Different Levels of Tiger nut seed meal. International Journal of Multidisciplinary Research and Review .Vol. 1 (1): 23-27.

Mangala, H.S and Mathew, G.R (1986) Direct feed microbials and their direct impact on the intestinal micro flora and immune system of chickens. Journal of Poultry Science 47:106-114.

Yanagita, K.., Shiraishi, J., Kawakami, S and Bungo, T (2011) Time course changes in the blood parameters and expression of diencephalic $\mathrm{CRH}$ and AVT mRNA due to acute isolation stress in chicks. J. Poult. Sci 48(2): 125-129. 